of the experimental psychologist, whose knowledge of psychoactive drugs could well be broadened, because the participants representing physiology, pharmacology, psychology and biochemistry laid emphasis, as could be expected, on the drug action rather than on the animal behaviour side of psychopharmacology.

A number of important issues were raised at the symposium. One which surely must merit future consideration is the role of the blood/brain barrier and blood/ cerebro-spinal fluid barrier in psychopharmacological investigations. For example, RNA administered systemically may effect the rate of learning in an animal (Cook), yet there is no evidence that RNA penetrates the $\mathrm{blood} / \mathrm{brain}$ barrier. It is also well known that if given intracerebrally rather than systemically, the biogenic amines can exert very different actions (Feldberg). In this connexion, one of the highlights of the symposium was the elegant work on the development of the blood' brain barrier in chicks, which showed how pharmacological, neurophysiological and behavioural techniques could be simultaneously applied to one problem (Dewhurst and Marley).

Another issue introduced was the importance of studying effects of drugs on social behaviour in animals (Chance and Silverman). Although this sort of approach appears promising, interpretation of the action of psychotropic drugs on social interactions among animals is difficult. It is questionable whether a drug which suppresses aggressive behaviour of rats possesses a corresponding effect on analogous behaviour in humans. However, in spite of methodological limitations, it is encouraging to learn that astute attempts are being made to translate the subtle psychogenic action of a drug from rodent to man.

The difficulties which may arise in the usage of behaviour analyses for drug evaluation were stressed (Irwin). For example, drugs can exert different effects if the animals tested differ in their "emotional and intellectual" pasts (Rushton and Steinberg), genetic backgrounds (Broadhurst), nutritional states (Watson), or even their familiarity with fellow test-subjects (Wilson and Mapes). With the use of the operant bar press as a research tool, a single drug may enhance a particular response topography with one schedule of reinforcement and depress it with another (Dews). Since reinforcement schedules can be varied ad infinitum, some interpretation is obviously desired in the meaning of the response change associated with changes in such schedules. One always wonders whether psychopharmacological studies utilizing an operant paradigm in animals with little or no cerebral cortex (birds) really bring us any closer to the understanding of psychoactive drugs, especially if these compounds are ultimately intended for clinical extension to humans.

Papers on the long-term effects of chronic administration of drugs were noticeably absent. Some coverage could have been given to those drugs which create pro. found social disturbances and on which experimental findings have emerged recently, namely ethyl alcohol, morphine, and other so-called 'addictive' compounds.

The discussion sessions which make up the final portion of the book were intended to be an organized exchange of ideas between the frequently divergent disciplines within the area of psychopharmacology. As a general impression it seemed that, in coming together, each discipline could be likened to an orchestral ensemble but each playing a different melody at the same time in the same concert hall. Because each contributor leaned almost entirely on the literature within his own discipline, discussion often was disjointed, lacking in continuity, and sometimes switched abruptly from one topic to another with important points hanging in the air.

In spite of this criticism, the organizers of the meetings must be congratulated on the final endeavour. By virtue of discussion sessions of the quality recorded in this volume, and as disciplines become better acquainted with one another's experimental techniques and points of view, future interdisciplinary meetings will become increasingly more fruitful.

R. D. MYers

\section{PALAEOCLIMATE AND PALAEOMAGNETISM}

\section{Problems in Palaeoclimatology}

Edited by A. E. M. Nairn. (Proceedings of the NATO Palaeoclimates Conference held at the University of Newcastle upon Tyne, January 7-12, 1963.) Pp. xiii +705. (London and New York: Interscience Publishers, a Division of John Wiley and Sons, Ltd., 1964.) 147s.

$7 \mathrm{HE}$ introductory article to Problems in Palaeoclimatology, by Prof. W. H. Bucher, is aptly entitled "The Third Confrontation". It draws analogies between the present impact on geological science of ideas on palaeogeography and palaeoclimates stemming from studies of rock magnetism, and the better-known geologicalgeophysical conflicts of the past concerning the age of the Earth and the origin of ocean basins. The reader of the book will doubtless find a fourth confrontation, between the apparent precision and repeatability of the palaeomagnetic observations (although their interpretation is still far from certain) and the failure of geologists to agree on the very nature of the phenomena which they seek to elucidate.

Thus in a series of successive geological articles on Precambrian glaciations, we find the conflicting conclusions: (1) "At present no Precambrian tillite has been sufficiently studied for us to accept glaciation without reservation"; (2) "The whole globe was glaciated in Eocambrian times"; and (3) "The evidence for late Precambrian glaciation is remarkably widespread". Without attempting to resolve these opposing opinions, it should perhaps be observed that recent dating work has shown many of the supposed late Precambrian 'tillites' to be more widely separated in age than is the Lower Cambrian from the Pleistocene; and that the presence of extensive phosphorites in the Sinian of China and Riphaean of Russia is scarcely compatible with the hypothesis of a lengthy and world-wide Precambrian glaciation, the end of which triggered off the rapid evolution of a Cambrian fauna.

A similar conflict is seen in the separate contributions of two authors on the late Precambrian conglomerate near Caen in Normandy, one of whom concludes that this formation is "as indicative as the Eocambrian fluvioglacial deposits of Norway or even the Quaternary fluvioglacial deposits of Poland", whereas the other asserts that "None of the data permits us to make inferences about climate. The climate could have been anything from tropical to glacial".

The work is, however, concerned with a great deal more than problems of Precambrian glaciation. It comprises no less than 54 contributions, arranged in chapters on the use of fossil plants in palaeoclimatic interpretation, the evidence of climate from coal and coal measures, the recognition of ancient glaciations, Precambrian glaciations, geophysical techniques and ancient climates, Devonian climate, theoretical considerations and Quaternary climate, the recognition of arid climate and wind direction studies, Permian climate, palaeontology and climate, and problems of red beds and soils. Dr. A. E. M. Nairn's editorial work is of outstanding quality, the diverse papers being bound together into these chapters by a unifying theme and by means of a well-summarized discussion at the end of each. Many of the contributions are entertainingly controversial and the book certainly deserves a place in every geological library for the use of mature readers, but it is to be regretted that the price is much higher than one expects to see for the report of a meeting which was financed from public funds.
C. F. DAVIDSON 